\title{
MALE MENOPAUSE AND DECISION-MAKING: A QUALITATIVE STUDY
}

\author{
GERRIT CLAASSEN \\ WILLEM SCHURINK \\ willems@acc.co.za \\ Dept of Human Resource Management \\ University of Johannesburg
}

\begin{abstract}
The purpose of this study was to explore how a small group of white South African men going through menopause attached meaning to this major event in their lives, and also how it affected the decisions they took as leaders in the financial sector. The findings indicated that menopause symptoms in particular (physical, psychological and sexual dimensions) had a profound influence on the systemic male. A provisional substantive theory was developed - "work power trade-offs result in decreased decision-making power during the male menopause" - and a number of recommendations were proposed.
\end{abstract}

\section{OPSOMMING}

Die doel van hierdie studie was om te verken tot hoe 'n mate 'n klein groep blanke Suid-Afrikaanse mans, wat tans in hulle menopouse is waarde daaraan heg en hoe die gebeurtenis hul lewens asook hul besluitneming as leiers in die finansiële sektor beinvloed. Die bevindinge het aangedui dat veral die manlike menopouse simptome ' $n$ sterk invloed op die sistemiese man uitgeoefen het. Die bevindinge het ook aanleiding gegee tot die formulering van 'n voorlopige substantiewe teorie wat gedefinieerd is as "werksmagverruiling (trade-offs) lei tot verminderde besluitnemingsmag gedurende die manlike menopouse fase".

There is considerable literature about the effect of aging upon men's physical, psychological and sexual health (Metz \& Miner, 1998). This aging "strikes at the core of what it is to be a man ... his youthful sexual drive and performance" (Sheehy, 1993, p. 163). More often than not, the idea that men experience a change of life equivalent to female menopause is the butt of jokes, and ridicule is directed at those who have proposed such an "unscientific notion" (Ducharme, 2002, p. 36).

While male menopause has always existed it has only recently been acknowledge and given its own identity as "andropause". The terms "male menopause", "viropause", "andropause", "male climacteric" (from the Greek word klimacter - the rung of a ladder) (Charlton, 2004; Nowak, 2000) and, more recently, the acronym ADAM (androgen decline in the aging male) have all been used in medical literature (Kessenich \& Cichon, 2001; Cetel, 2002; Nowak, 2000). The term androclise ("clise" in Greek meaning slowly diminishing) is clinically a more correct description, but still not appropriate for all men (Charlton, 2004). The World Health Organisation meeting in Paris 2003 and the World Congress on the Aging Male in Prague, 2004, suggested two definitive terms: the Aging Male Syndrome (AMS) or late onset hypogonadism (Charlton, 2004).

While male menopause is not the equal of female menopause, many men lose potency, energy and drive between 40 and 80 years of age. Sheehy (1994) calls it "the unspeakable passage," a process that starts during a man's 40 s to 50 s and chews away relentless at his strength, his sexuality and his general sense of contentment (Cowley \& Kalb, 1996, p. 69). Despite the significant impact this phenomenon has had not only on men but also on the partners they live with, it has until quite recently been poorly understood if not practically ignored. One can only speculate as to the reasons for this. Is it perhaps a touch of male denial in the predominantly male medical community? Has this then contributed to the undercurrent of controversy that exists even today regarding the validity of the male climacteric - despite the significant impact it has on men's lives and on the lives of the women with whom they live (Cetel, 2002)?

Requests for copies should be addressed to: W. Schurink, willems@acc.co.za
"What is male menopause"? While not predictable, this phenomenon occurs mainly in middle adulthood (age 40-60) when men's testosterone production and plasma concentrations fall. In aging men, the reduction in testosterone concentration is due mainly to a decline in Leydig cell mass in the testicles, or to a dysfunction in the hypothalamic-pituitary homeostatic control, or both, leading to abnormally low secretion of luteinising hormones with resultant low testosterone production (Gould, Petty \& Jacobs, 2002).

Symptoms of the hormonal decline accompanying aging male hormonal withdrawal can be divided into three categories, namely: physical, psychological and sexual symptoms (Kessenich \& Cichon, 2001). Physical symptoms include fatigue, decreased capacity for physical exercise, decreased muscle strength; sleep disturbances, loss of short-term memory, and both increased body fat and urinary frequency (Kessenich \& Cichon, 2001). Psychological symptoms are irritability, depression, anxiety, loss of self-confidence, difficulty concentrating, and indecisiveness (Kessenich \& Cichon, 2001). For many older men sexual symptoms are probably the most bothersome and may be the chief reason that they seek medical attention. Hormonal decline in aging men may also lead to decreased libido, impotency, erectile dysfunction, and an overall reduced interest in sex (Kessenich $\&$ Cichon, 2001). These clinical symptoms are reported by a number of researchers and it is evident that there is a general consensus among scholars regarding the symptoms of male menopause (Ducharme, 2002; Metz \& Miner, 1998). In a recent study Charlton (2004) suggests a fourth category called endocrine. Its typical symptoms are flushes, erectile dysfunction, reduced erectile quality, dry skin, joint and muscle aches and decreased body hair. This category represents a strong overlap with the physical symptoms already discussed.

It is to be expected that profound physiological changes will have an influence on many, if not all, aspects of a man's life. Small wonder then that the typical symptoms of male menopause are well documented in the literature. However, surprisingly, the effect of these symptoms on the "systemic male" has not been explored in any depth. Nonetheless, a number of research projects have been undertaken on the influence of depression on menopausal men (Milne, 1999; 
Seidman, Araujo, Roose \& McKinlay, 2001). Particularly notable is the "quality of life questionnaire" (QoL) that has recently been validated by Novak, Brod and Elbers (2002).

Despite developments like these, very little research has been undertaken on the influence of male menopause in the boardrooms of big business. Since declining testosterone has such a widespread influence on the "systemic male", the relationship between this natural aging process and decision-making should be investigated after all, "managers have to make decisions; it is their responsibility" (Oldcorn, 1998).

Decision-making as a rational, deliberate, purposeful action, beginning with the development of a decision strategy and moving through the appraisal of results occurs in all organizations. The process is the same even if the content is different in different cases (Tarter \& Hoy, 1998). Decision-makers are primarily human beings who eat, sleep, have families and a variety of interests; diversity and compromise is the stuff of their everyday existence (Tarter \& Hoy, 1998). Given this context of male leader decision-making, addressing quality of life issues, dealing with midlife transition, growing old, and on top of it all, being let down by their "most prized asset", life for menopausal men can indeed be very demanding. It gives new meaning to the anonymous saying: "Middle age is when you have the choice of two temptations and choose the one that will get you home earlier".

At the age of 40 to 50 most men have reached the peak of their careers or what development psychologists refer to as "middle adulthood" (Louw, 1995; Levinson, 1978). As already mentioned, this is also the beginning of the male midlife passage or the onset of male menopause (Sheehy, 1997a). From a synoptic review of the literature it is clear that while a number of studies have explored the effect of menopause on men, the majority of them followed a medical approach and only a few have thus far studied the broader psychological and career/work-related influences of male menopause. Inevitably the main focus of these studies has been to address the symptoms of declining testosterone in aging men.

Work enhances many men's feelings of power and therefore it is understandable that they would have the urge to prove themselves and their masculinity. Levinson (1978) describes the transition from early adulthood to midlife as a time when man feels obliged to reappraise his life structure. This process has been described as often leading to disillusionment, since men recognise that long-held assumptions or beliefs about maleness and the world are not necessarily true. For example, in North American society, men are typically taught that the key to personal growth and achievement is work, and that virtually all personal needs for creative expression, status, security, freedom and love will be met as a direct function of occupational achievement (Samson, 1977 in Metz \& Miner, 1998).

Midlife is further complicated and perhaps even triggered by the aging process, which indicates the beginning of male menopause. This life stage has various implications for business since individuals in key positions at this stage often terminate their careers, resulting in the loss of critical competencies, and a decline in productivity (Hutchison, 2003). Moreover, work morale is low, and worst of all, extramarital affairs at work often occur. Thus, male menopause ultimately has broad and varied implications for both individual and business. While not all men experience menopause similarly, all are aging, and this prompts them to realise that at some stage they will have to face their mortality.
From the preceding discussion, it is clear that career longevity issues are being brought into the boardroom by the male menopause.

\section{DECIDING TO STUDY MALE MENOPAUSE AND DECISION-MAKING IN A SOUTH AFRICAN FINANCIAL INSTITUTION}

Having explored various literature sources, and being unable to trace any existing scientific knowledge on South African men's menopause and how it impacts on their careers, and specifically their leadership responsibilities and tasks, Claassen decided to launch an explorative study in an attempt to explore this phenomenon. More particularly, he decided to undertake an in-depth study of the lives of a few authentic white South African men who have been experiencing menopause and have occupied leadership positions for some years in a financial institution, in South Africa's Gauteng Province. He believed by undertaking this research we would be able to shed light on these men's experiences of this stage in their life cycle and the challenges it poses to them at work. Moreover, we assumed that obtaining first-hand insight into these men's social world would not only contribute towards scientific knowledge locally, but would also lead to the development of strategies to assist male leaders in the corporate world to adjust to menopause and the challenges it poses. Further, we were convinced that by applying an appropriate qualitative methodological approach that is increasingly being favoured among researchers of leadership and organisations abroad, ${ }^{1}$ a contribution to local methodology would be made since it would illustrate practically how such a methodological approach could be adopted in relation to male menopause and decision-making in the South African context.

\section{Core assumptions}

In the study we applied an interpretive social science approach. Our scientific beliefs correlate closely with those of Terre Blanche and Durrheim (1999): i.e. any reality to be studied consists of people's subjective experiences of the external world (ontology). Our stance was interactional epistemological towards social reality, and we employed a methodology that relied on a subjective relationship between the subjects and the researcher. For interpretive research, the goals of social science are to develop an understanding of social life and to discover how people construct meaning in their natural settings.

Qualitative research is primarily concerned with issues of the richness, texture and feeling of raw data because of its inductive approach, which emphasises the development of insight and understanding from the data collected (Neuman, 2003). The transcendent perspective fits the interpretive approach well since research questions originate from the standpoints of the people being studied, and not that of outsiders (Neuman, 2003). We worked from the premise that the wisdom and knowledge required to understand the interaction of male menopause and decision-making is vested in the research participants.

By conducting a qualitative study our aim was to generate knowledge and insight into male menopause and business decision-making. In this way we wanted to establish knowledge about a relatively new dimension of leadership behaviour as influenced by physiological processes in an organisational context. Moreover, we hoped that through applying a formal qualitative inferential method, grounded theory, the findings of the study might lead to the creation of a substantive theory on male menopause as it relates to decision-making in the work sphere. Finally, Claassen looked forward to gaining a better understanding of his own menopause within his career and psychosocial context. 


\section{METHOD}

\section{Selecting research participants}

We made use of a combination of convenient and purposive selection. Based on Claassen's knowledge of the organisation and its people, we identified two indigenous hierarchies in the bank - senior and executive management - and it was from these ranks that we enrolled participants ${ }^{2}$. We developed the following criteria, which Claassen applied in selecting the participants: (a) male employees between 45 and 55 years of age, since the literature indicates that men in this age category experience menopause; and (b) male employees in leadership positions within the organisation.

Claassen personally approached leaders falling into these categories and invited them to take part in the study. Making use of people who are knowledgeable about the organisation further enriched our selection of participants. Claassen interviewed these informants in order to discover and share insights they had of the financial institution as well as to elicit suggestions as to possible research candidates and themes for the study. Based on the above criteria, advice from informants and Claassen's personal knowledge of the organisation, we finally chose five leaders (including Claassen) in leadership positions in the organisation to participate in the study.

Claassen obtained official permission from the financial institution to approach potential research participants while certain "gatekeepers" who could grant him access to these potential participants were also informed.

In described and exploring male menopause and decisionmaking in the work environment, we decided to conduct a series of three in-depth interviews with each participant. ${ }^{3}$

The socio-demographics of the men participating in the study - including Claassen - can be summarised as follows: (i) their ages ranged from 44 to 52 years, (ii) the men were all white, (iii) were married, (iv) had children, and (v) had formal qualifications (three had postgraduate certificates in the behavioural sciences while the other two had commerce credentials). The participants all occupied senior management levels in the bank. With a single exception, all of them grew up and lived in South Africa's metropolitan centres. Not unexpectedly, despite the interviewees' homogeneity in terms of colour and race, their differences in background emerged in their unique worldviews. We are satisfied that, within the context of the research and given the various practical constraints, we managed to select a group of men who represented confident senior leaders of the financial institution with established beliefs and views regarding marriage, aging, relationships and decision-making.

\section{Applying grounded theory}

We opted for Strauss and Corbin's (1990) application of grounded theory. We applied this approach within the requirements of modernist qualitative research, i.e., we attempted to provide sufficient information to establish the study's credibility. In addition, we strove to provide the participants with a voice in the study. Against this background we made inferences by applying three analytical steps, namely: open coding, axial coding and selective coding.

\section{Open coding}

Open coding is the process of breaking down and conceptualising the data (Strauss and Corbin, 1990). This process starts from the moment the first data is created (Holloway \& Wheeler, 2002). This phase brings to the surface themes from the data "at a low level of abstraction" and from the initial research questions (Neuman, 2003, p. $443)$. As the coding process progresses the level of abstraction increases. The following twenty-four themes emerged during the open coding phase including the broad category from which they emerged:

\section{TABle 1}

OPEN CODING THEMES

\begin{tabular}{|c|c|c|}
\hline $\begin{array}{l}\text { Theme } \\
\text { no. }\end{array}$ & Theme category & Broad categories \\
\hline 1 & Decline in physical power & Physical symptom \\
\hline 2 & Changing sleep patterns and insomnia & Physical symptom \\
\hline 3 & $\begin{array}{l}\text { Decline in physical appearance and wellness } \\
\text { versus fantasies of revived youth and health }\end{array}$ & Physical symptom \\
\hline 4 & $\begin{array}{l}\text { Decline in self-confidence, mood-swings and } \\
\text { the inability to change }\end{array}$ & $\begin{array}{l}\text { Psychological } \\
\text { symptom }\end{array}$ \\
\hline 5 & $\begin{array}{l}\text { Questioning the purpose of work and the } \\
\text { emergence of anxiety }\end{array}$ & $\begin{array}{l}\text { Psychological } \\
\text { symptom }\end{array}$ \\
\hline 6 & $\begin{array}{l}\text { The inability to control emotions versus } \\
\text { insight in emotional integration }\end{array}$ & $\begin{array}{l}\text { Psychological } \\
\text { symptom }\end{array}$ \\
\hline 7 & $\begin{array}{l}\text { Decline in sexual power due to a weakening } \\
\text { sexual appetite and drive }\end{array}$ & Sexual symptom \\
\hline 8 & $\begin{array}{l}\text { Marriage at mature age is not related to } \\
\text { waning sex drive }\end{array}$ & Sexual symptom \\
\hline 9 & Female depersonalisation as a defence & Sexual symptom \\
\hline
\end{tabular}
mechanism for the loss of sexual power and
sexual appetite

10 Declining sexual need versus increasing freedom in relationship giving meaning to life

11 Increased value and the importance of family life

12 Men's psychological feelings of comfort arising from their insight into changing experiences

13 Emerging of personal values

$14 \quad$ Paradoxes

15 Contradictions in male menopause experience: control at work versus loss of control in marriage

16 Experiencing loss due to aging

17 Increased death awareness and the projecting of immortality onto external objects

18 Increasingly satisfying work experience

Sexual symptom

Changing

relationships

Changing

relationships

Changing relationships

Changing relationships

Changing relationships

Sense of loss Sense of loss

Work experience Work experience due to psychological integration

20 The South African socio-political landscape and employment equity legislation

21 The inability to control emotions leading to emotional decisions being made

22 Easier decision-making facilitated by the Decision-making menopause

23 Wise decision-making

Decision-making

24 Situational decision-making approach Decision-making

With regard to the open coding used in the study the following deductions can be made: (i) the men experienced a general decline in power; (ii) they reported physical, psychological and sexual symptoms which they believed had profound effects on their behaviour and decision-making; (iii) post-apartheid South African employment equity played a profound role in channelling them to deal with their careers in a different way much earlier in their careers; (iv) due to the aging process they experienced a sense of loss which mainly focused on physical appearance, sexual decline, and a decline of power in the financial institution; (v) anxiety and stress manifested in the majority of the themes emerging during open coding; (vi) decision-making patterns changed during menopause; it appeared that wisdom emerged as the key driver of these changes, and (vii) the men appeared to be satisfied 
with the new values they discovered - like the significance of their families.

\section{Axial coding}

Axial coding implies a process of reassembling data, i.e. describing a category (phenomenon) in terms of the conditions giving rise to it; its context or the specific set of properties in which it is embedded; the actions/interactional strategies by which it is handled, managed and carried out; and the consequences of those strategies (Strauss \& Corbin 1990). We needed to integrate codes around the axes of central categories which we accomplished by: (i) exploring, discussing and relating the themes identified during the open coding; (ii) integrating and reducing the themes, grouping new themes that emerged or themes together under existing themes; (iii) reviewing notes Claassen made during the study; (iv) exploring menopause symptoms as experienced and perceived by the men before we combined and related themes to each other; (v) grouping the symptoms reported by the men, into three broad categories, namely: physical, psychological and sexual symptoms since they correlated largely with those we identified in prominent scholarly works; (vi) battling with: "What is causing these symptoms to emerge during menopause"?; (vii) in order to reassemble the data created in the open coding phase relating each emerging new theme to the other themes; and (viii) having completed this process relating all of these to the central research question - namely, "How does these themes influence decision-making in the work context?"

The themes we managed to infer from the men's accounts and related to both salient abstract theoretical concepts and the empirical findings available in the relevant literature are:

TABLE 2

\section{Axial CODING THEMES}

\begin{tabular}{ll}
\hline Theme 1 & Men experiencing a decline in power \\
Theme 2 & Sense of loss \\
Theme 3 & Changing relationships in the menopause \\
Theme 4 & Positive work experience \\
Theme 5 & $\begin{array}{l}\text { Perceived new realities during the menopause leading to } \\
\text { inner peace }\end{array}$ \\
Theme 6 & Menopause and its symptoms leading to stress and anxiety
\end{tabular}

In relating these categories to decision-making at work (the central research question of the study), we re-discovered the following key phrases by reviewing Claassen's field notes and the transcribed interviews: (i) being more impatient with people; (ii) having the necessary knowledge to influence decision-making; (iii) being more direct than previously; (iv) reaching high levels of confidence; (v) obtaining quality decision-making; (vi) experiencing irritation and frustration in the work environment (linked to decision-making); (vii) making easier decisions; (viii) taking more decisions but being less afraid to take them; (ix) not making any decisions; and $(\mathrm{x})$ displaying more emotion during decision-making. We discovered that these did not convey a strong tale, but as soon as one integrated them with the preceding six themes, an illuminating story appeared. In tracing these themes and stories back to the current leadership and literature on decision-making new insights emerged.

Leadership characteristics in the decision-making process were of special importance to this study and it was clear from our scrutinising of the available literature that the somewhat chaotic characteristics and requirements found in it represented building-blocks that could assist leaders to effect good-quality decisions. It also became clear that the particular decision approach decided upon, the particular decision model selected, and the specific characteristics or decision competencies utilised, changed continuously according to the urgency of the situation, the strategic level of the decision, budget constraints, and external environmental influences. This context facilitated insight into how leaders in their menopause take decisions. Utilising the insight gained from the six themes extracted during axial coding, and combining them with the understanding brought about by explicating the decision-making process and consulting the relevant scholarly literature, we were able to relate the six themes more precisely to decision-making.

\section{Selective coding}

The final level of grounded theory entails selective coding, i.e. the process of selecting a core category that emerges during axial coding and relating it to the other categories (Strauss \& Corbin, 1990). Here the essential task is to develop a single theory line around which all themes can be "draped"; this represents the highest level of abstraction of the data. In executing this phase we integrated both supportive and contradictory literature relating to the core theme. We believe that one important outcome of reviewing the literature was the discovery of the link between male menopause and the human life cycle, particularly middle adulthood. Studying the implications of this linkage assisted us in placing the findings of the core theme in context, thus allowing the provisional substantive theory to emerge.

The core theme emerging in the study centres on "the decreased need for work power in the workplace due to psychological integration during the male menopause phase".

The men followed a process of psychological integration in order to settle for less work power than they had before. It became clear that this came about as part of a systemic interaction between the themes that emerged during axial coding. The interaction and interplay between a decline in power, a sense of loss, changing relationships, experiencing work as positive, accepting new realities, and stress and anxiety, all contributed to the emergence of the central theme. Experiencing work as positive and accepting new realities were indeed very positive themes, which should have assisted the men to ease the effect of menopause. As a result of the changing socio-political landscape and the introduction of employment equity legislation in the workplace, the participants realised early in their careers that they had to accept the new social reality. Being in their menopause and dealing with its associated changes, work became even more important to these men: on the one hand they wanted to retain their work, and on the other, they used this as an anchor to deal with life's transitions and uncertainties. Through a process of psychological integration, the men accepted these new realities. One of these was to cope with a decreased need for work power since the influence and decision-making power of white leaders in the organisation had decreased remarkably. For leaders to relinquish power is indeed not easy to do since the public recognition accompanying senior positions, internally and external to their company, is important to them.

The men's menopause also influenced their physical wellbeing. The reported menopause symptoms resulted in a decline in power, an experience of a sense of loss, and changing relationships. The psychological influences of these themes culminated in relatively high stress and anxiety levels. Changing work practices (men being forced to retire earlier, and then finding it difficult to find employment again) and uncertain career prospects due to employment equity legislation might have acted as the final pressure on the participants to settle for decrease work power through a process of psychological integration. This appeared to ensure career longevity in the organisation. 
In putting the core theme together, the emergence of key influencers of behaviour - namely frustration, selfdoubt, becoming more emotional, blaming the organisation for robbing one of important life events, and resentment were confirmed again. With a decreased need for personal power it can be assumed that the men would experience declining decision-making authority and influence in the organisation. The participants were perhaps inclined to demonstrate less personal work power since aging white men do not have real decision-making authority in the organisation any longer.

This trend led to a decline in self-confidence, which, in turn, resulted in frustrations in both family and work environments. The men began to question their lives and work, resulting in stress building up. They were more emotional during menopause, which gave rise to emotionally charged decisions. Frustration, self-doubt, and resentment clearly moved them to respond more emotionally towards work challenges. This further resulted in them as white leaders being overly cautious in decision-making in order not to risk their employment contracts. The men have limited options in the organisation and it is understandable that they would not risk losing their jobs through risky decisionmaking. It appeared that they became more cautious in their decision-making, which perhaps explains why none of them made mention of often taking high-risk decisions. As already indicated, it is quite ironic that while these men have been in their positions and job level for some time, and clearly have the ability to make difficult high-risk decisions, they in stead rely on their experience and the wisdom they have gained over the years. In doing this they believed that they could control their emotions and display more tolerance in the decision process.

\section{Emergence of substantive theory}

We are convinced that the substantial and rich data that Claassen gathered enabled us to accomplish this vision in at least, provisionally and/or partly building a substantive theory. Selective coding and relating the themes both with each other and the core theme paved the way for such theory. We believe that the phrase "work power trade-offs result in decreased decision-making power during the male menopause phase" substantially illuminates the main theme. We identified three different work power trade-off situations leading to decreased decision-making power explaining this phenomenon:

- White male leaders in the organisation expressed a need for less work power due to psychological integration, that is coping with changes in the organisation, accepting a changing role in the organisation and realising that one is aging since one is moving through menopause;

- Less work power is needed as a result of the socio-political changes and employment equity legislation (white leaders have less value and power in the work situation in their male menopause phase); and

- The men settled for less work power since they did not reach their personal work goals and at the same time menopause created the awareness that they are aging and would because of this probably not reach these goals anyway. This awareness is compounded by limited career opportunities for white leaders in the organisation.

According to the literature the idea of relinquishing work power as the result of a sense of loss and personal vulnerability associated with aging is particularly unattractive to senior leaders in organisations (Kets de Vries, 2001). Past research illustrates that some leaders display a great intentness and singlemindedness to maintain power. Interesting enough the present study suggests the opposite: white leaders within the sociopolitical realities of South Africa appear to sacrifice some of their work power, resulting in them having decreased power to make decisions in the organisation.
It appeared that the men participating in the present study used work power trade-offs to survive in the bank, to stay relevant, to deal with changes in the organisation, and certainly not to challenge the emerging black leadership regime.

Subsequent investigation into whether similar power trade-offs occur in the family situation proved worthwhile. It appeared that the men relied more on their wives during their menopause than before and actually enjoyed it! This is supported by the literature. This is supported by the literature and in particular by the so-called double menopause suggesting the unconscious existence of a complementary personality (Cetel, 2002). Anima represents a man's unconscious feminine side, while animus is a woman's unconscious masculine side. Mid-life appears to lower the threshold of the expression of anima and animus. In the menopausal male androgen hormonal levels decline and the relative levels of female hormones increase (Cetel, 2002; Sheehy, 1997; Segell, 1996). It can thus be deduced that hormonal changes would influence the psychology and psyche of men. It therefore appears that menopause might be a prompt for men to get more in touch with their female side. In the work context this may manifest as a further aspect of work power trade-off. In contrast, in the family context this may manifest as a shift in power resulting in a different focus - the power to realise long-held unfulfilled dreams which anima in mid-life enables.

\section{DISCUSSION}

I gained a number of first-hand insights into male menopause and its influence on decision-making within organisations. Despite these discoveries, additional research questions emerged which may be constructed as hypotheses and explored in future research initiatives. While these did not necessarily emerge during the selective coding phase, they are:

- The use of paradoxes as a sensitising concept in the participants' stories to share their worldviews and experience of male menopause.

- A renewed discovery of the powerful influences of typical male menopause symptoms on the systemic male in the work and social context.

- Participants marrying late in life do not experience the decline in sexual drive that was reported by men who married early.

- The discovery of the powerful influences of the changing socio-political landscape and employment equity legislation in South Africa on men's realities at work and experience of their menopause.

- The physical roots of the male menopause appear to be the catalyst that sets this life stage in motion and it should not be underestimated. In the study it manifested in "a decline in power".

- The unobtainable desire expressed by the men to be young and healthy again, while doing very little to achieve it.

- Stress does not necessarily reduce the sex drive: it in fact possibly even increases it - while the physical sexual performance required to satisfy is lacking.

- Female depersonalisation as a defence mechanism for the loss of sexual power.

- The acknowledgment of a lack in career-planning in the organisation, with the participants using their careers (albeit coincidental and unplanned) as an anchor in dealing with their menopause.

- The participants' view that since they had already taken a number of important decisions in their lives before the onset of their menopause there was no need to take anymore important decisions.

- The emergence of wisdom as a prevalent theme in the accounts of the participants with regard to the decision-making process. 
- The greater tolerance of participants in decision-making.

- The emergence of a situational decision-making approach.

These "discoveries" supported the study's emerging core theme, namely: "the decreased need for work power in the work environment due to psychological integration" as well as its substantive theory: "work power trade-offs result in decreased decision-making power during the male menopause phase".

\section{Noticeable shortcomings}

The process of grounded theory research is extremely timeconsuming and the volumes of data generated by applying this approach can be overwhelming. In the present study it was essential to manage the volumes of data within the parameters of practical constraints. While only a small number of people could consequently be enrolled in the research, a massive amount of material was still generated by the approach, which proved very challenging for Claassen as lone researcher ${ }^{4}$. The following are particular shortcomings that emerged:

(1) In essence this research represents a case study in a prominent financial institution. The small sample obviously, as with qualitative studies generally, limited the extent to which its findings can be generalised (external validity). Similar research employing grounded theory but including larger samples of leaders in the particular financial institution or across financial institutions should be considered. According to Neuman (2003) the best sample size depends on three things: (a) the degree of accuracy required; (b) the degree of variability in the population; and (c) the number of variables observed simultaneously. In the context of this study a smaller sample was sufficient since less accuracy was acceptable (the depth was more important), the population was homogeneous and only a few variables were examined at a time.

(2) The reliability and validity of this study were particularly challenging. By following an autoethnographical approach Claassen took special care not to project his own biases onto the data. Throughout the study we followed and applied specific interventions to ensure the reliability and validly of the study. We used Lincoln and Guba's (1985) criteria to assess the trustworthiness of the study:

- Truth value: We established the truth value of the study by giving the men free choice of research participation, assuring them of anonymity and privacy, conducting interviews with informants to identify potential participants who were regarded as knowledgeable, allowing the participants to select the interview sites, making the transcribed interviews available to them and, finally, conducting various member validation interviews with them.

- Applicability: Since the study represents a case study of a financial institution, the sample used limits the extent to which the study can be applied to other contexts or subjects. However, given the depth of the exploration we are of the opinion that the findings can be applied to other contexts and participants. This assumption is especially relevant since all white males between 45 and 60 in South Africa are experiencing menopause and are influenced by the changing socio-political changes and employment equity legislation. However, this does not suggest a broad applicability.

- Consistency: As Schurink (2004) points out, qualitative research is exceptionally unpredictable. Small wonder that decisions and steps are typically taken while the research is being conducted, and not before it commences. "Although some of these decisions can be noted in the report, it is not possible to reproduce all the steps followed in a particular investigation in such a way that a blueprint is given for other researchers who wish to replicate the study" (Schurink 2004, p. 12). In the current study Claassen endeavoured to outline the key decisions taken during the study as well as the reasons for taking them via the natural history. We believe that this does not mean that the results of this study cannot be tested in further research. There is at least amongst modernist qualitative researchers a tendency to search for "cases that contradict the findings and encourage the verification of results without needing to repeat the original investigation" (Schurink 2004, p.12).

- Neutrality: Member validations were used extensively in this study. In addition, the voices of the participants were also conveyed via the excerpts of their accounts 5 . These offer the reader the opportunity to assess the interpretation of the themes that emerged from the data.

The accounts presented by the interviewees could have been influenced by the fact that Claassen knew some of them and had business dealings with them from time to time in the organisation. This might have had an influence on the reliability and validity of the study. We are of the opinion, however, that the consistent research procedures we followed ensured that these business relationships did not turn into personal biases. The member validations also offered the participants the opportunity to reflect on their personal contributions and my interpretations of the data.

Despite the obvious shortcomings of this study we are convinced that they were not detrimental to its findings. We are convinced that the careful interpretations of the findings within the context of these limitations enabled valid (although, of course, not flawless) deductions regarding the men's worldviews particularly as they relate to menopause and decision-taking in a particular local financial institution.

\section{Personal reflections}

Claassen's personal reflections of this study varied widely from ecstatic and challenged, to frustrated and uncertain. He experienced the same feelings as Pandit (1996): to work with ground theory involves lengthy periods of uncertainty. He had to display a lot of patience, faith and persistence to execute the process properly. The pleasure of new interesting discoveries emerging, however, made it all worthwhile.

The most gratifying experience of the study was certainly the interaction with the participants. This did not lie only in the conversations but also in the journey of insight both the participants and Claassen gained. The immense curiosity on the side of the participants to read the final report was also a continuous source of inspiration and motivation for him. In retrospect, the strongest motivator for Claassen was the opportunity to hand each participant a final copy of the study. $\mathrm{He}$ also sensed that their curiosity was linked to a need for increased insight into their own menopause and how it might influence their decision-making in the financial institution, of which they are employees. We truly hope that the insights gained and recommendations made in the study will live up to the participants' expectations and will assist them to appreciate both their conscious and unconscious behaviour to settle for less work power while at the same time losing their decisionmaking power.

\section{Recommendations}

The recommendations we offer relate to the following broad areas: Leadership and Change studies, male menopause and decision-making, theory and methodology. Finally, we present suggestions particularly relevant to the financial institution where the research was undertaken.

\section{Leadership and Change studies}

With regard to Leadership and Chang studies we suggest:

- Additional studies need to be undertaken focusing on the leadership life cycle and male menopause. Men reach senior leadership positions in the organisation when the effect of 
aging and menopause become noticeable (Kets de Vries, 2003), yet the true impact of this life-stage event is not fully understood from a leadership perspective.

- Although this is not directly related to leadership studies, we also want to suggest that male menopause and its "position" and relationship to the middle adulthood life stage should be defined clearly. There is currently no clarity in this regard in the available literature. Clarity here will benefit students in future leadership life-cycle studies since male menopause plays a key role in a specific life stage.

- The emergence of a substantive leadership theory - namely, that white leaders in their menopause settle for less work power, which results in decreased decision-making power needs to be explored further. Within the changing sociopolitical landscape and employment equity in the local work context in South Africa this phenomenon may have a dramatic influence on white leadership in both an organisational and country context.

\section{Male menopause and decision-making}

With reference to the findings pertaining to male menopause and its influence on decision-making in the work context the following proposals are relevant:

- Leaders need to be more aware of the physical, psychological and sexual changes associated with middle adulthood and male menopause. The study highlighted the systemic influences of these symptoms and the associated stress and anxiety created by the changes.

- Men do not undertake the journey associated with aging and menopause on their own. Their families and, specifically, partners need to be aware of this life stage and obtain the necessary insight into the changes influencing their men.

- Leaders in their menopause phase must be specifically sensitised in order to become aware of, and deal with, the systemic influence of stress and anxiety accompanying this life stage.

- Men in general and leaders specifically must take care when redefining relationships during their menopause stage. This life stage is associated with middle adulthood where one of the main tasks is redefining relationships (Hutchinson, 2003). Due to the complexity and varied nature of relationships, this is a particularly challenging task.

\section{Grounded theory}

Making suggestions in relation to theory-building in grounded theory studies specifically and qualitative research generally is no easy matter. Nevertheless, based on our experience with the present study, we suggest:

- Specify as part of the study's purpose whether any attempt will be made as to create a theory by means of the grounded theory approach.

- Ensure an understanding of the grounded theory approach and its varieties in order to guarantee that the research findings, emerging concepts and resultant theory are properly grounded in the data.

- Appreciate that qualitative and grounded theory studies are underpinned by symbolic interactionism (Locke, 2001; Collis \& Hussey, 2003).

- Researchers need to appreciate personal exposure to the study before embarking on it. This is of specific importance in an autoethnographic approach, which demands a high level of personal sharing and involvement.

- Be specific as to the precise nature of the envisaged theory.

- Be sure to allow sufficient time to create theory.

We have already shared some views and perceptions regarding grounded theory as a methodological approach in qualitative research. In view of his own experiences in the present study, Claassen offer the following two additional observations:

- While there is controversy as to when and how extensively the relevant theoretical and empirical literature should be applied in grounded theory research, such review must be undertaken at some point after the researcher has been exposed for some time to the social world he or she is studying. Scrutinising the available literature on the subject under study is essential for exploring and possibly aligning the different views and experiences of those who are part of the research. Grounded theory appears to be particularly complicated and confusing for first-time users and therefore an appropriate literature study will assist them considerably. “ ... Glaser (1978) acknowledges that some pre-emergent analytic thinking is necessary for the 'emergent fit' model of grounded theory. A researcher cannot come into a topic ... completely cold. The researcher must have some predetermined idea of the things about which the subjects will be questioned, without asking explicitly about esoteric topics from the existing leadership literature. Thus, questioning of subjects should revolve around a range of leadership-related topics ... Having said this, existing leadership theories must not be considered until after the grounded theory has been generated. Obviously, the emergent theory must be compared with the existent leadership literature. This will avoid the possibility of existing theories or biases being 'forced' into the data gathered. At most, they will provide a mere backcloth to data collection" (Parry, 1998, p. 94).

- Quantitative research is clearly favoured in South African leadership studies. The academic community should assist in advocating and following a balanced approach in teaching both quantitative and qualitative approaches. Schurink (2003) recently conducted a literature search on qualitative research in local management and organisational studies and came to the conclusion that the literature on qualitative research in South Africa is limited. He (Schurink 2003) coincidentally came to the same conclusion as the above when he stated that a tradition of qualitative research does not exist in the local institutions of higher learning.

\section{The financial institution}

In assisting male leaders who are experiencing menopause the following broad areas are particularly important:

\section{Educational intervention}

- The bank should consider designing interventions equipping male leaders with life skills enabling them to deal with career and life-stage transitions and to cope effectively with life changes like male menopause.

- Special interventions for leaders in senior positions should be designed to address added the stress and anxiety associated with life-stage and menopause changes. The key focus should be on restoring a balance in life.

- Reading material should be provided on the organisation's intranet portal to assist in creating an awareness of the systemic influences of male menopause in the work situation.

- A special attempt should be made to educate families of male leaders who are moving into their menopause. This should apply to female leaders as well.

- According to the works of Sayegh et al. (2004) and Ford and Gioia (2000), the organisation should consider leadership interventions to nurture both the emotional side and the creative side of decision-making.

\section{Comprehensive career counselling}

- The organisation needs to assist male leaders approaching their menopause or those already in this life-cycle phase with comprehensive career planning. This is specifically relevant for current white leaders since they are experiencing sociopolitical changes in South Africa and the introduction of employment equity; their career progression in the organisation has reached a premature ceiling and they are responding by expressing a decreased need for work power. Comprehensive career-planning should ensure career longevity and reduce resentment towards the organisation for robbing them of opportunities, and it should also influence the quality of decision-making positively. 
- We found in the study that work plays an important role in the lives of male leaders. In the light of this the organisation needs to address the paradox that work is important for these leaders, and they are on top of their technology, but the organisation is rendering them obsolete earlier in their careers (Sheehy, 1997a). This phenomenon leads to high levels of anxiety and it appears to affect the quality of organisation decision-making.

\section{Counselling}

- The organisation should consider training facilitators or counsellors who can assist male leaders in their midlife transition and menopause. This recommendation relates closely to the education programme and careerplanning in the organisation suggested above.

- Medical support for leaders with health issues should be readably available. The organisation has already implemented an executive health-care program, which offers an ideal opportunity to integrate male menopause counselling.

- Trauma debriefers should be trained to deal with crises male leaders might experience during this life stage, even if it is only to refer the leader to an appropriate counsellor.

- Male leaders in their middle adulthood and menopause should also be trained to act as mentors to younger employees. This will facilitate the removal of barriers between old and young. In addition, as Erikson (Levinson, 1978) points out, leaders could assist in the process of generativity.

\section{REFERENCES}

Cetel, N. (2002). Double Menopause: What to do when both you and your mate go through hormonal changes together. New Jersey: John Wiley \& Sons, Inc.

Charlton, R.D. (2004). Ageing male syndrome, andropause, androgen decline or midlife crises? The Journal of Men's Health and Gender, 1 (1), 55-59.

Collis, J. \& Hussey, R. (2003). Business research: A practical guide for graduate and postgraduate students. (2nd ed.). New York: Palgrave Macmillan.

Cowley, G. \& Kalb, C. (1996). Attention: Aging men. Newsweek, 128 (12), 69-77. Retrieved January 24, 2003, from EBSCOHOST database.

Ducharme, S.H. (2002). Male menopause: The real thing? Paraplegia News, 56 (11), 36-38.

Ford, C.M. \& Gioia, D.A. (2000). Factors influencing creativity in the domain of managerial decision-making. Journal of Management, 26 (4), 705-732.

Gould, D.C., Petty, R. \& Jacobs, H.S. (2002). The male menopause: Does it exist? British Medical Journal, 320 (7238), 858. Retrieved January 21, 2004, from Infotrac database.

Holloway, I. \& Wheeler, S. (2002). Qualitative research in nursing. (2nd ed.). Oxford: Blackwell Science Ltd.

Hutchinson, E.D. (2003). Dimensions of Human Behaviour: The Changing Life Course. (2 $2^{\text {nd }}$ ed.). London: Sage Publications.

Kessenich, C.R. \& Cichon, M.J. (2001). Hormonal decline in elderly men and male menopause. Geriatric Nursing, 22 (1), 24-28.

Kets de Vries, M.F.R. (2001). The leadership mystique: An owner's manual. London: Pearson Education Limited.

Kets de Vries, M.F.R. (2003). Leaders, Fools and Impostors: Essays on the Psychology of Leadership. New York: iUniverse, Inc.

Levinson, D.J. (1978). The seasons of a man's life. Toronto: The Random House Ballantine Publishing Group.

Lincoln, Y.S. \& Guba, E.G. (1985). Naturalistic Inquiry. Newbury Park: Sage Publications.
Locke, K. (2001). Grounded Theory in Management Research. London: Sage Publications.

Louw, D.A. (1995). Human Development, Cape Town: ABC Book Printers.

Metz, M.E. \& Miner, M.H. (1998). Psychosexual and Psychosocial aspects of male aging and sexual health. Canadian Journal of Human Sexuality, 7 (3), 245- 260. Retrieved January 24, 2003, from EBSCOHOST database.

Milne, C. (1999). Coming to grips with depression. Maclean's, 112 (8), 32. Retrieved January 24, 2004, from EBSCOHOST database.

Neuman, W.L. (2003). Social Research Methods: Qualitative and Quantitative Approaches. (5 $5^{\text {th }}$ ed.). Boston: Allyn and Bacon.

Novak, A., Brod, M. \& Elbers, J. (2002). Andropause and the quality of life: Findings from patient focus groups and clinical experts. Maturitas, 43 (4), 231-237.

Nowak, R. (2000). Life in the old dog. New Scientist, 167 (2248), 36. Retrieved January 21, 2003, from Infotrac database.

Oldcorn, R. (1998). Management. Hampshire: Macmillan Education Ltd.

Pandit, N.R. (1996). The creation of theory: A recent application of the Grounded Theory method. The Qualitative Report, 2 (4). Retrieved April 19, 2004, from http:// www.nova.edu/sss/QR/QR2-4/pandit.html.

Parry, K. W. (1998). Grounded Theory and Social Process: A new direction for Leadership Research. Leadership Quarterly, 9 (1), 85-105.

Sayegh, L., Anthony, W.P. \& Perrewe, L. (2004). Managerial decision-making under crisis: The role of emotion in an intuitive decision process. Human Resource Management Review, 14 (2), 179-199.

Schurink, W.J. (2003). Methods in qualitative research: Grounded theory. Anne Crafford's programme in Industrial Psychology presented at Master's Programme, Rand Afrikaans University, Johannesburg, 8 October 2003.

Schurink, W.J. (2004). Lecture Thirteen: Evaluating Qualitative Research. Rand Afrikaans University, Study School, 27-28 February 2004

Segell, M. (1996). The new softness (why men become more intimate and nurturing in later life). Esquire, 125 (4), 51(1). Retreived January 21, 2003, from Infotrac database.

Seidman, S.N., Araujo, A.B., Roose, S.P. and McKinlay, J.B. (2001). Testosterone level, androgen receptor polymorphism, and depressive symptoms in middle-age men. Biological Psychiatry, 50 (5), 371-376.

Sheehy, G. (1993, April). The unspeakable passage: Is there a male menopause? Vanity Fair, p. 163.

Sheehy, G. (1994). The Silent Passage: Menopause. London: HarperCollins Publishers.

Sheehy, G. (1997a). New Passages: Mapping your life across time. London: HarperCollins Publishers.

Sheehy, G. (1997b). Beyond virility, a new vision: Men and their doctors need to understand that impotence is just one part of a complicated midlife passage - call it MANopause. Newsweek, 130 (20), 69(1). Retrieved January 21, 2003, from Infotrac database.

Strauss, A.L. and Corbin, J. (1990). Basics of Qualitative Research: Grounded Theory Procedures and Techniques, Thousand Oaks: Sage Publications.

Tarter, C.J. \& Hoy, W.K. (1998). Toward a contingency theory of decisionmaking. Journal of Educational Administration, 36 (3), 212-228.

Terre Blanche, M. \& Durrheim, K. (1999). Research in practice: Applied methods for the social researcher. Cape Town: University of Cape Town Press. 